\title{
ROLE OF INTRALESIONAL CORTICOSTEROID THERAPY IN EYELID HAEMANGIOMA
}

Shashi Shekhar Prasad ${ }^{1}$ Ranjeet Kumar ${ }^{2}$

1 Professor, Department of Ophthalmology, Patna Medical College, Patna, Bihar.

Junior Resident, Department of Ophthalmology, Patna Medical College, Patna, Bihar.

HOW TO CITE THIS ARTICLE: Prasad SS, Kumar R. Role of intralesional corticosteroid therapy in eyelid haemangioma. J. Evolution Med. Dent. Sci. 2017;6(74):5324-5325, DOI: 10.14260/Jemds/2017/1155

\begin{tabular}{ll}
\hline PRESENTATION OF CASE & namely endothelial cells.(2,4,5) Early lesions are very cellular \\
A 2-month-old female child presented in P.M.C.H Eye O.P.D & with solid nest of plump endothelial cells and little vascular \\
with an occlusive lesion involving the right upper eyelid, & lumen. Histologically, the lesion is composed of lobules of \\
which resulted in ptosis within early weeks of normal & capillaries separated by sparse fibrous septae. The capillaries \\
delivery as told by mother. The lesion increased in size over & $\begin{array}{l}\text { may infiltrate the underlying subcutaneous lesion and muscle } \\
\text { in lobular configuration. The increased fibrosis and }\end{array}$ \\
the past one and a half month without any systemic feature. & $\begin{array}{l}\text { hyalinisation of capillary walls with luminal occlusion show } \\
\text { that lesions are involuting. }(2,3)\end{array}$
\end{tabular}

On Examination of eye and adnexa, it was suggestive of a superficial cutaneous lesion (Strawberry naevi) bright red on the right upper eyelid.(1) There was difficulty in opening of right eyelid fully and left eye showed fixing following. On measurement of lids the right palpebral fissure was $2 \mathrm{~mm}$ while left palpebral fissure was $10 \mathrm{~mm}$. The orbital ultrasonography revealed no intraorbital extension.

\section{DIFFERENTIAL DIAGNOSES}

- $\quad$ Nevus flammeus (port-wine stain) of Sturge-Weber syndrome.

- Lymphangioma or other vascular malformation.

- Metastatic neuroblastoma.(2)

- Kasabach-Merritt syndrome.

\section{Course}

The examination and history of patient consistent with a capillary haemangioma of right upper eyelid resulting in partial occlusion of involved eye. Orbital ultrasonography demonstrated no intraorbital extension of lesion.

\section{CLINICAL DIAGNOSIS}

The diagnosis of infantile haemangioma is done by history and physical examination in majority of cases.(3) Imaging ultrasound with Doppler, magnetic resonance imaging and cytology or histopathology are also used in rare cases for confirmatory diagnosis. The depth of involvement can also be ascertained by ultrasonography. The blood flow into the lesion can be demonstrated by CT scan. MRI scan can also be helpful.

\section{PATHOLOGICAL DISCUSSION}

Capillary haemangioma are classified as hamartomas or abnormal proliferation of normal tissue in normal location

Financial or Other, Competing Interest: None

Submission 16-06-2017, Peer Review 01-09-2017,

Acceptance 07-09-2017, Published 14-09-2017.

Corresponding Author:

Dr. Shashi Shekhar Prasad,

Professor, Department of Ophthalmology,

Patna Medical College and Hospital,

Patna, Bihar.

E-mail: drshashishekharpd@gmail.com, dr.ranjeetpmch@gmail.com

DOI: $10.14260 /$ jemds $/ 2017 / 1155$

\section{(c) (i) $\$$}

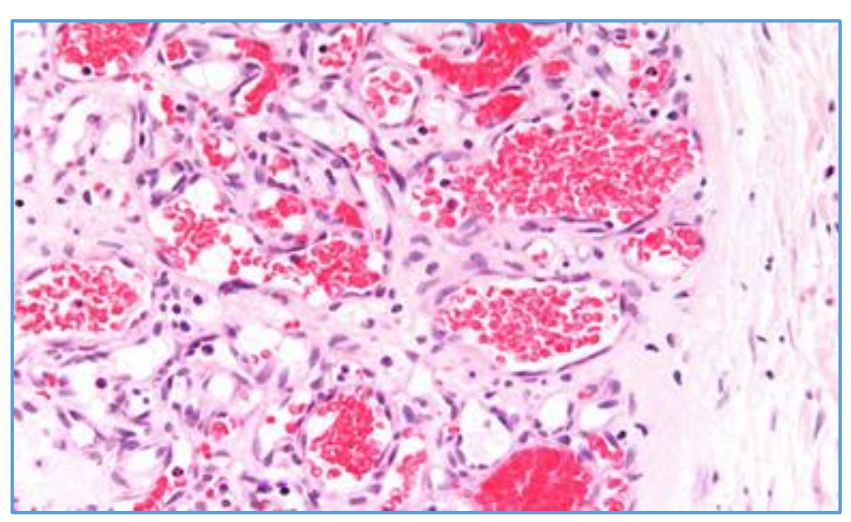

Histopathologic Picture of Capillary Haemangioma showing Lobules of Capillaries separated by Fibrous Tissue

\section{Treatment}

Both long and short term acting intralesional injectable steroids are useful in these type of cases; $1 \mathrm{~mL}$ of short-acting triamcinolone $(40 \mathrm{mg} / \mathrm{mL})$ is mixed with $1 \mathrm{~mL}$ of long-acting betamethasone $(4 \mathrm{mg} / \mathrm{mL})$ in tuberculin syringe and injected in the lesion.(6,7) With a single use of intralesional injection, most of the haemangiomas reduced. In this case we had given repeated injection at an interval of six weeks. After the six months of two intralesional injections of corticosteroid, there was excellent regression in tumour size.

Propranolol, a non-selective beta-blocker that can be used systemically for orbital capillary haemangioma with high efficacy. ${ }^{(8)}$

Surgical treatment is rarely indicated, but can be considered in those with visual symptoms, not responding to pharmacologic modalities of management. $(6,9)$

\section{DISCUSSION OF MANAGEMENT}

Spontaneous involution is the rule. Observation is also necessary. In the natural course of time there is $40 \%$ complete involution by the age of 4 yrs., whereas $80 \%$ complete involution by the age of 8 yrs.(10,11) If there is occlusion amblyopia or significant astigmatism, treatment must be started earlier for the best result. The intralesional steroid treatment carries a risk of soft tissue atrophy, hypopigmentation, glaucoma and possible systemic absorption.(12) 


\section{CONCLUSION}

This case highlights the importance of intralesional corticosteroid therapy in the management of regressing eyelid haemangioma as an initial modality.

\section{REFERENCES}

[1] Drolet BA, Esterly NB, Frieden IJ. Hemangiomas in children. N Eng J Med 1999;341(3):173-81.

[2] American academy of ophthalmology. Ophthalmic pathology and intraocular tumors. Basic and clinical science course 2010-2011.

[3] Vemuganti GK, Honavar SG. Stromal tumor. In: Pe'er, Singh AD. eds. Clinical ophthalmic oncology: eyelid and conjunctival tumors. $2^{\text {nd }}$ edn. Berlin: Springer 2014:79-94.

[4] North PE, Waner M, Brodsky MC. Are infantile hemangiomas of placental origin? Ophthamology 2002;109(4):633-4.

[5] Lo K, Mihm M, Fay A. Current theories on the pathogenesis of infantile hemangioma. Semin Opthalmol 2009;24(3):172-7.

[6] Egbert JE, Schwartz GS, Walsch AW. Diagnostic and treatment of an ophthalmic artery occlusion during an intralesional injection of corticosteroid into an eyelid capillary haemangioma. Am J Opthamol 1996;121(6):638-42.
[7] Ranchod TM, Friedon IJ, Fredrick DR. Corticosteroid treatment of periorbital haemangioma of infancy: a review of the evidence. $\mathrm{Br} \mathrm{J}$ Opthamol 2005;89(9):1134-8.

[8] Vassallo P, Forte R, Di Mezza A, et al. Treatment of infantile capillary haemangioma of the eyelid with systemic propranolol. Am J Opthamol 2013;155(1):165-70.e2.

[9] Haik BG, Karcioglu ZA, Gordon RA, et al. Capillary haemangioma (infantile periocular haemangioma). Surv Opthmol 1994;38(5):399-426.

[10] Haik BG, Jakobiec FA, Ellsworth RM, et al. Capillary hemangioma of the lid and orbit: an analysis of the clinical features and therapeutic results in 101 cases. Ophthalmology 1979;86(5):760-92.

[11] Ceisler E, Blei F. Ophthalmic issues in hemangiomas of infancy. Lympht Res Biol 2003;1(4):321-30.

[12] Boon LM, MacDonald DM, Mulliken JB. Complication of systemic corticosteroid therapy for problematic hemangioma. Plast Reconstr Surg 1999;104(6):161623. 